\title{
HUBUNGAN PEMBERIAN MAKANAN TAMBAHAN PADA IBU HAMIL DENGAN KURANG ENERGI KRONIS DI WILAYAH KERJA PUSKESMAS IBRAHIM ADJIE KOTA BANDUNG TAHUN 2018
}

\author{
Yeti hernawati' ${ }^{1,}$ Rallyvia Kartika ${ }^{2}$ \\ ${ }^{1,2)}$ Program Studi Diploma Tiga Kebidanan STIKes Dharma Husada Bandung \\ Hernawati.yeti@gmail.com
}

\begin{abstract}
ABSTRAK
Kurang Energi Kronik (KEK) adalah kurangnya asupan energi berlangsung lama. Pada ibu hamil KEK merupakan keadaan ibu hamil menderita kekurangan energi yang berlangsung menahun sehingga menimbulkan gangguan kesehatan. Keadaan gizi ibu yang buruk sebelum kehamilan dan selama kehamilan cenderung melahirkan bayi dengan berat badan lahir rendah, bahkan kemungkinan bayinya meninggal. Penelitian ini bertujuan untuk mengetahui hubungan pemberian makanan tambahan terhadap ibu hamil KEK di wilayah Puskesmas Ibrahim Adjie Tahun 2018. Metode penelitian menggunakan metode deskriptif dengan pendekatan cross-sectional. Diambil dari data sekunder buku register puskesmas Ibrahim adjie periode Januari - April 2018. Sampel yang digunakan adalah $42 \mathrm{ibu}$ hamil KEK. Analisis data menggunakan univariat, dilakukan dengan perhitungan statistik kemudian ditampilkan dalam tabel distribusi frekuensi. Hasil penelitian didapatkan ibu hamil KEK yang mendapatkan pemberian makanan tambahan selama 4 bulan sebanyak $73.68 \%$. Sedangkan rata-rata kenaikan nilai pengukuran lingkar lengan atas (LILA) ibu yang kurang energi kronik diberikan makanan tambahan selama 90 hari adalah $2 \mathrm{~cm}$. Analisis data secara bivariat menggunakan uji statistik Chi Square dengan $\alpha=0,05$. Hasil uji Chi Square menunjukkan terdapat hubungan yang signifikan antara pemberian makanan tambahan pada ibu hamil dengan Kurang Energi Kronis (KEK) di wilayah kerja puskesmas ibrahim adjie periode Januari - April 2018.
\end{abstract}

Kata Kunci : Pemberian Makanan Tambahan, Kehamilan, Kurang energy Kronik ( KEK)

\section{PENDAHULUAN}

Kehamilan merupakan suatu investasi yang perlu dipersiapkan, dalam proses ini gizi memiliki peran penting untuk menunjang pertumbuhan dan perkembangan janin. Untuk menunjang dan mempercepat tercapainya tujuan perbaikan situasi gizi ibu, diperlukan juga upaya pendidikan dan penyebarluasan informasi kepada pihak yang terlibat langsung maupun tidak langsung dan tercapai. ${ }^{2}$

Status gizi yang baik merupakan
merupakan salah satu faktor penentu
keberhasilan pembangunan kesehatan yang

pada dasarnya adalah bagian yang tak terpisahkan dari pembangunan nasional secara keseluruhan. Anak balita, anak usia sekolah, dan ibu hamil merupakan kelompok rawan gizi yang sangat perlu mendapat perhatian khusus karena dampak negatif yang ditimbulkan apabila menderita kekurangan gizi.

Empat masalah gizi utama di Indonesia yaitu Kekurangan Energi Protein (KEP), Gangguan Akibat Kekurangan Yodium (GAKY), Kekurangan Vitamin A (KVA), dan Anemia Gizi Besi (AGB). Di Indonesia banyak terjadi kasus KEK (Kekurangan Energi Kronis) 
terutama yang kemungkinan disebabkan karena adanya ketidakseimbangan asupan gizi (energi dan protein), sehingga zat gizi yang dibutuhkan tubuh tidak tercukupi. Hal tersebut mengakibatkan pertumbuhan tubuh baik fisik ataupun mental tidak sempurna seperti yang seharusnya. Ibu hamil yang menderita KEK mempunyai risiko kematian ibu mendadak pada masa perinatal atau risiko melahirkan bayi dengan berat lahir rendah (BBLR).

Berdasarkan Riskesdas tahun 2013 diketahui bahwa prevalensi ibu hamil risiko KEK sebesar $24,2 \%$. Ibu hamil dengan status KEK dapat berdampak pada pertumbuhan dan kesehatan bayinya. Pemberian makanan tambahan khususnya bagi kelompok rawan merupakan salah satu strategi suplementasi dalam mengatasi masalah gizi.

Berdasarkan data yang diperoleh dari buku Register UPT Puskesmas Ibrahim Adjie periode Januari 2018 - April 2018 jumlah ibu hamil yang melakukan pemeriksaan ANC adalah 315 orang dan ibu hamil yang mengalami KEK berjumlah 57 orang. ${ }^{27}$

Ibu hamil risiko KEK yaitu ibu hamil dengan hasil pengukuran LILA lebih kecil dari 23,5 cm. Makanan Tambahan Pemulihan adalah suplementasi gizi dalam bentuk makanan tambahan dengan formulasi khusus dan difortifikasi dengan vitamin dan mineral yang diperuntukkan bagi kelompok sasaran sebagai tambahan makanan untuk pemulihan status gizi. MT Ibu hamil adalah suplementasi gizi berupa biskuit lapis yang dibuat dengan formulasi khusus dan difortifikasi dengan vitamin dan mineral yang diberikan kepada ibu hamil dengan kategori Kurang Energi Kronis (KEK) untuk mencukupi kebutuhan gizi. Sasaran utama MT Ibu hamil adalah Ibu hamil risiko KEK. Setiap ibu hamil KEK diberikan MT sebanyak 3 bungkus biskuit selama 1 bulan.

Ibu yang mengalami KEK selama masa kehamilan akan berdampak negatif pada siklus kehidupan keturunannya. Studi membuktikan bahwa ibu dengan status gizi kurang dapat menyebabkan gangguan pertumbuhan janin dan melahirkan bayi dengan berat badan lahir rendah yang ditandai dengan berat badan lahir kurang dari 2.500 gram. $^{3}$

Penelitian dilakukan pada ibu hamil di UPT Puskesmas Ibrahim Adjie untuk mengetahui hubungan pemberian makan tambahan pada ibu hamil dengan kurang energi kronis (KEK).

\section{METODE PENELITIAN}

Dalam penelitian ini penulis menggunakan penelitian secara kuantitatif dengan desain korelasi, yaitu penelitian yang diarahkan untuk menjelaskan hubungan antara dua variabel yaitu variabel bebas dengan variabel terikat. Penelitian ini bertujuan untuk mengetahui hubungan mengkonsumsi makanan tambahan ibu hamil terhadap KEK pada ibu hamil. 
Pendekatan waktu dalam penelitian ini menggunakan penelitian cross sectional (poin time approach) artinya, tiap subyek penelitian hanya diobservasi sekali saja dan pengukuran dilakukan terhadap status karakter atau variabel subyek pada saat penelitian. Hal ini tidak berarti bahwa semua subyek penelitian diamati pada waktu yang sama.

Kerangka konsep penelitian yang diteliti adalah hubungan pemberian makanan pendamping pada ibu hamil dengan Kurang Energi Kronis (KEK).

Bagan 1. Kerangka Konsep Penelitian

\begin{tabular}{|c|c|c|}
\hline Makanan & & $\begin{array}{l}\text { Kurang Energi Kronis } \\
\text { (KEK) }\end{array}$ \\
\hline Tambahan & $\Longrightarrow$ & \\
\hline Ibu Hamil & & $\begin{array}{l}\text { Ya }: \text { LILA }<23,5 \mathrm{~cm} \\
\text { Tidak : LILA }>23,5 \mathrm{~cm}\end{array}$ \\
\hline
\end{tabular}

Variabel Independen penelitian yaitu pemberian biskuit makanan tambahan. Sedangkan variabel Dependen yaitu ibu hamil KEK.

Populasi pada penelitian adalah seluruh ibu hamil trimester I yang mengalami KEK di Puskesmas Ibrahim Adjie pada bulan Januari April 2018 sebanyak 57 ibu hamil. Teknik pengambilan sampel yang digunakan oleh peneliti adalah Total Sampling. Total Sampling adalah teknik pengambilan sample dimana jumlah sample sama dengan populasi. Alasan mengambil total sampling karena menurut Sugiyono (2007) jumlah populasi yang kurang dari 100 seluruh populasi dijadikan sampel penelitian semuanya Teknik pengambilan sampel yang digunakan oleh peneliti adalah Total Sampling. Total Sampling adalah teknik pengambilan sample dimana jumlah sample sama dengan populasi. Alasan mengambil total sampling karena menurut Sugiyono (2007) jumlah populasi yang kurang dari 100 seluruh populasi dijadikan sampel penelitian semuanya. Jadi, sampel yang diperlukan disini adalah 57 responden berdasarkan buku Register ANC UPT Puskesmas Ibrahim Adjie periode Januari - April 2018.

Instrumen penelitian berupa Data Buku Register Pemeriksaan ANC dan Kohort UPT Puskesmas Ibrahim Adjie periode Januari April 2018. Metode pengumpulan adalah suatu proses pendekatan kepada subjek dan proses Ya:Lhe ${ }^{\text {penpulan }} 23,5 \mathrm{~cm}$ kakteristik subjek yang diperlukan dalam suatu penelitian. Data Tidak : LILA $>23,5 \mathrm{~cm}$ adala data yang diperoleh peneliti dari sumber data yang sudah ada.

Peneliti melakukan izin penelitian kepada pihak Puskesmas Ibrahim Adjie. sebelum dilakukannya penelitian, peneliti menjelaskan tujuan dan persetujuan penelitian ini kepada pihak dengan memberikan lembar perizinan. Sebelum melakukan penelitian untuk mendapatkan data sekunder yang dibutuhkan, peneliti meminta izin untuk melakukan penelitian kepada pihak UPT Puskesmas Ibrahim Adjie. Penelitian ini dilakukan di UPT Puskesmas Ibrahim Adjie dijalan Ibrahim Adjie no 88 Kota Bandung. Setelah 
mendapatkan persetujuan barulah peneliti melakukan penelitian dengan menekankan masalah etika.

Pengolahan data dilakukan secara univariat dan bivariat. Analisa univariat bertujuan untuk menjelaskan atau mendeskripsikan karakteristik setiap variabel penelitian. Pada umumnya analisis ini hanya menghasilkan distribusi dan presentase dari tiap variabel yang diteliti. ${ }^{26}$ Analisa bivariat bertujuan untuk mencari hubungan kebiasaan mengkonsumsi biskuit makanan tambahan pada ibu hamil dengan KEK maka dilakukan uji statistik dengan metode Chi Square $\left(\mathrm{x}^{2}\right)$.

\section{HASIL DAN PEMBAHASAN}

\section{Analisis Univariat}

Tabel 4.1 Distribusi Frekuensi Pemberian Makanan Tambahan Pada Ibu Hamil

\begin{tabular}{lcc}
\hline Kategori & F & $\%$ \\
\hline Diberikan selama 4 bulan & 42 & 73,68 \\
$\leq 4$ bulan & 15 & 26,32 \\
\hline Total & 57 & 100 \\
\hline
\end{tabular}

Dari hasil tabel 4.1 dapat dilihat bahwa dari 57 responden yang diteliti berdasarkan pemberian Makanan Tambahan Ibu Hamil periode Januari - April 2018, terdapat 42 responden $(73.68 \%)$ diberi makanan tambahan selama 4 bulan full, dan 15 responden (26.32\%) tidak diberi makanan tambahan selama 4 bulan full. Pemberian Makanan Tambahan (PMT) dibiayai dari dana Bantuan
Operasional Kesehatan (BOK). Dari data yang didapat UPT Puskesmas Ibrahim Adjie.

Berdasarkan teori yang didapat, tujuan pemberian makanan tambahan ini adalah untuk pemulihan gizi berbasis makanan lokal bagi ibu hamil dengan KEK. PMT dilakukan selama 90 hari dan evaluasi setiap bulan dengan melihat pertambahan berat badan dan LLA, sehingga status gizi ibu menjadi normal. ${ }^{13} \mathrm{Hal}$ ini didukung dari hasil penelitian yang dilakukan di Kota Surabaya, mengemukakan bahwa pemberian makanan tambahan mampu memberikan perubahan status gizi ibu hamil KEK menjadi normal. ${ }^{14}$

Hasil penelitian menunjukkan bahwa terjadi peningkatan pada ibu hamil kurang energi kronis setelah diberikan makanan tambahan berupa biskuit dengan bahan dasar pangan lokal dengan kandungan energi 474,75 kkal dan protein 18,4 gram.

Beberapa faktor yang dipertimbangkan dalam pemilihan jenis produk adalah produk sudah dikenal dan memiliki citarasa yang baik sehingga disukai serta diterima masyarakat secara luas, praktis, punya daya simpan relatif lama dan mudah dalam penyajiannya. Aspek lain yang dipertimbangkan adalah komposisi gizi produk. Jenis produk terpilih berupa biskuit Hal ini sejalan dengan hasil penelitian N A Taslim, (2010) ibu hamil kurang energi kronis yang menerima PMT yang mengandung kurang lebih 600-700kkal dan 15-20 g protein setiap hari selama 3 bulan berturut-turut dan 
tablet besi yang berisi $60 \mathrm{mg}$ ferrous sulfate dan 0,025mg asam folat, menunjukkan bahwa terjadi peningkatan rata-rata kadar hemoglobin sesudah 3 bulan intervensi secara bermakna. Pengaturan makan ibu hamil akan mempengaruhi kecukupan zat gizi dan status gizi ibu hamil.

\section{Analisis Bivariat}

Setelah dilakukan penelitian untuk melihat adanya hubungan bermakna antara variabel bebas dan variabel terikat, yaitu hubungan kebiasaan mengkonsumsi biskuit makanan tambahan pada ibu hamil dengan KEK maka dilakukan uji statistik dengan metode Chi Square (x2). Berdasarkan output SPSS di atas dapat dilihat bahwa nilai chi-Square hitung sebesar 22.902, dan p-value $(0,000)$ dibawah nilai $\alpha(0.05)$, maka: H0 ditolak. Artinya terdapat hubungan yang signifikan antara mengkonsumsi makanan tambahan ibu hamil terhadap KEK berdasarkan pengukuran Lingkar Lengan Atas (LILA) ibu di UPT Puskesmas Ibrahim Adjie periode Januari April 2018.

Setelah melakukan wawancara dengan bidan selaku petugas kesehatan yang berada di UPT Puskesmas Ibrahim Adjie didapatkan hasil mengapa banyak ibu hamil yang mengalami KEK rutin memeriksakan keadaannya kepuskesmas karena faktor kesadaran, kepatuhan ibu dan terpantaunya dari kelas ibu hamil yang dilakukan oleh bidan yang berkunjung pada saat posyandu ke daerah tersebut. Hal ini ditemui dalam teori kesadaran diri yaitu kondisi dimana seorang individu memiliki kendali penuh terhadap stimulus internal maupun stimulus eksternal. Namun, kesadaran juga mencakup dalam persepsi dan pemikiran yang secara samar-samar disadari oleh individu sehingga akhirnya perhatiannya terpusat.

Hasil penelitian V. Prihananto (2007) menunjukkan rata-rata tingkat kepatuhan konsumsi ibu hamil kurang energi kronis yang diberikan makanan tambahan berupa produk biskuit adalah paling tinggi (94.0\%). Hal ini sejalan dengan hasil penelitian yang dilakukan di Jawa Timur oleh Kusin dan Kardjati pada tahun 1994 pemberian makanan tambahan dengan 465 kalori dan 7,1 gram protein tidak berpengaruh terhadap berat bayi lahir namun hasil meta analisis PMT dengan energy 300 $800 \mathrm{kkal} / \mathrm{hari}$ dengan energy yang berasal dari protein $<25 \%$ dapat meningkatkan tambahan berat badan ibu hamil yang menderita KEK (Kramer, 1997 diambil dalam Anwar et al., 2003) .

\section{SIMPULAN SAN SARAN}

Berdasarkan hasil penelitian mengenai "Hubungan Pemberian Makanan Tambahan Pada Ibu Hamil Dengan Kurang Energi Kronis (KEK) Di Wilayah Kerja Puskesmas Ibrahim Adjie Periode Januari - April 2018”, dari 57 ibu hamil KEK dapat disimpulkan bahwa Sebagian besar responden (73.68\%) diberi 
makanan tambahan selama 4 bulan dan memiliki rata - rata kenaikan pengukuran Lingkar Lengan Atas (LILA) sebesar $2 \mathrm{~cm}$, Terdapat hubungan yang signifikan antara pemberian makanan tambahan pada ibu hamil dengan Kurang Energi Kronis (KEK) di wilayah kerja puskesmas ibrahim adjie periode Januari - April 2018. ( $\mathrm{p}<0,05)$.

Tenaga kesehatan bekerja sama dengan kader - kader Posyandu dan tokoh masyarakat, untuk lebih meningkatkan pengetahuan dan pendidikan masyrakat, khususnya ibu hamil yang mempunyai gizi kurang dengan cara penyuluhan dan dilakukan dengan rutin serta pemasangan poster atau media komunikasi lainnya yang berhubungan dengan pemberian Makanan Tambahan sehingga dapat mencegah serta dapat meningkatkan cakupan status gizi ibu hamil. Bidan dapat meningkatkan kualitas intervensi dan kolaborasi dengan tenaga gizi, dalam memberikan asuhan terhadap ibu hamil dengan KEK mengenai konseling kadarzi dan pemberian makanan tambahan. Serta berkolaborasi mengenai pembuatan makanan lokal dengan tenaga gizi. Hal ini dapat dilakukan pada saat pelaksanaan kelas ibu hamil.

Diharapkan penelitian ini dapat menambah bahan referensi yang berhubungan dengan Makanan Tambahan ibu hamil sehingga dapat menambah wawasan dan kepedulian mahasiswa tentang ibu hamil yang mengalami KEK.

\section{DAFTAR PUSTAKA}

Ani, LS. 2016.Buku Saku Anemia Defisiensi Besi. Jakarta : EGC

Anika. I. 2008. Hubungan Pendidikan Dan Sikap Ibu Hamil Tentang Tablet Zat Besi Dan Kepatuhan Ibu Hamil Dalam Konsumsi Tabletj Besi. Karang Awen : Unimus

Arisman, MB. 2014. Buku Ajar Ilmu Gizi : Obesitas, Diabetes Mellitus, \& Dislipimedia : Konsep Teori dan Penanganan Aplikatif. Jakarta : EGC

Arisman. 2004. Gizi dalam Daur Kehidupan. Jakarta : EGC

Arikunto, S. 2013. Prosedur Penelitian : Suatu Pendekatan Praktik. Jakarta : Rineka Cipta

Dapartemen Kesehatan RI. 2011. Profil Kesehatan Indonesia. Jakarta

.Febianty, N. 2013. Perbandingan Pemeriksaan Kadar Hemoglobin Dengan Menggunakan Metode Sahli dan Auotoanalyzer Pada Orang Normal

Fikriana, U. 2013. Faktor - faktor yang Mempengaruhi Kejadian Anemia pada Ibu Hamil. Bantul : Naskah Publikasi

.Istiarti, Tinuk. 2010. Menanti Buah Hati.Yogyakarta : Media Persindo

Kemenkes RI. 2013. Profil Kesehatan Indonesia. Jakarta : Kemenkes RI

Manauaba, Ida Bagus Gede. 2007. Pengantar Kuliah Obstetri. Jakarta : EGC

Notoatmodjo, S. 2010. Metodologi Penelitian Kesehatan. Jakarta : Rineka Cipta

Nugroho, Taufan. 2010. Kesehatan Wanita, Gender dan Permasalahannya. Yogyakarta : Nuha Medika

Mitaaerdila. 2013. Jurnal Budaya Kehamilan dan Persalinan 
Nursalam. 2011. Konsep Dan Penerapan Metodologi Penelitian Ilmu Keperawatan Profesional Edisi 4. Jakarta : Salemba Medika

Nugroho. 2012. Patologi Kebidanan. Yogyakarta : Nuha Medika

Prawirohardjo. 2010. Ilmu Kebidanan. Jakarta : Bina Pustaka Sarwono Prawirohardjo

Riset Kesehatan Dasar (Riskesdas). 2015. Badan Penelitian dan Pengembangan Kesehatan Kementrian RI. Jakarta

Sugiyono. 2011. Metode Penelitian Kuantitatif dan $R \& D$. Bandung : Alfabeta

Survey Demografi Kesehatan Indonesia. 2013. Angka Kematian Ibu. Jakarta

Saifuddin AB. 2009. Panduan Praktis Pelayanan Kesehatan Maternal dan Neonatal. Jakarta : EGC
Sembiring, R. 2010. Hubungan Anemia dalam Kehamilan dengan Kejadian Perdarahan Post Partum Volume 2. Medan : Jurnal DIII Kebidanan Mutiara Indonesia

Sulistyoningsih H. 2011. Gizi untuk Kesehatan Ibu dan Anak. Yogyakarta : Graha Ilmu

Soebroto, I. 2009. Cara mudah mengatasi problem Anemia. Yogyakarta : Bangkit.

Wawan A., \& Dewi M. 2010. Teori dan Pengukuran Pengetahuan, Sikap, dan Perilaku Manusia. Yogyakarta : Nuna Medika

Widiyanto S.Y.D. 2001. Hubungan Pengetahuan, Sikap, dan Praktek Ibu Hamil dengan Kepatuhan Minum Tablet Besi. Yogyakarta : Universitas Gadjah Mada. Tesis

Wiknjosastro, Hanifa. 2007. Ilmu Kebidanan. Jakarta : Yayasan Bina Pustaka Sarwono Prawirohardjo

World Health Organization (WHO). 2015. Angka Kematian Ibu. Amerika : WH 